Revista Iberoamericana, Vol. LXVIII, Núm. 200, Julio-Septiembre 2002, 567-582

\title{
EL AMERICANO NUEVO Y SU ACTITUD POÉTICA
}

POR

Jorge Carrera Andrade

\section{CONTRIBUCIÓN A LA FELICIDAD HUMANA}

La imagen geográfica del Continente descubierto por equivocación, era aún primitiva e imperfecta, como un mapa dibujado por un niño, en los siglos XVI, XVII y XVIII. Los hombres europeos de esas épocas se representaban a América como un vago territorio, compuesto de países “siempre verdes” y cubierto de fundaciones españolas, especialmente iglesias y palacios de virreyes. Más allá, se encontraba el Mar Océano con sus monstruos acuáticos que se sumergían y salían a la superficie, sin cesar, señalando el fin del mundo. En mayor grado que la magia o la alquimia, el descubrimiento de América había encendido la esperanza humana. Las más variadas leyendas se echaron a volar en ese favorable tiempo de candor y fe en lo maravilloso: el reino de El Dorado, el País de la Canela y de las Amazonas, la Fuente de la Eterna juventud, el Tesoro Sepultado de los Incas. Esas leyendas obedecían a la sed de felicidad experimentada por la humanidad antigua; felicidad que ésta cifraba en la posesión de tres bienes únicos: el oro, la mujer y la salud.

Los galeones españoles llevaban, en efecto, oro y piedras preciosas con destino al viejo mundo. Y en lo que se refiere a las amazonas, los conquistadores las encontraron en el suelo americano en gran número, ya domesticadas, pasivas y hacendosas, y con un gusto por la servidumbre que fue de inmensa utilidad para sus planes de colonización de esas nuevas tierras. Pero, en mayor grado aún que el oro y demás beneficios, otros agentes más modestos, igualmente oriundos de América, estaban contribuyendo a la felicidad humana el tabaco, el cacao, la coca. Era el generoso aporte de la agricultura mágica de los indios.

El tabaco, procedente de las tierras antillanas, transformó el vivir europeo. Introdujo el ensueño en la sociedad batalladora de las pasadas épocas. Impuso la pausa reflexiva, con el hábito de aspirar por las narices un polvo de rapé o dar una chupada a la pipa. Despejó el cerebro del hombre y aclaró su mente, envolviendo el vivir en un velo tenue de intimidad cordial. Llevó al espíritu una impresión de quietud confortable o, mejor, de calma dichosa.

De igual manera, el chocolate fue un humilde reformador de la vida española. Su aparición contribuyó al desarrollo de la sociabilidad, haciendo posible la tertulia en que se ejercita la inteligencia. Ese cuadro habitual de una familia feliz de los siglos pasados - en Cádiz o en Logroño- donde se muestra al abuelo envuelto en una venturosa nube de humo azul, y mujeres y mozos alegres charlando animadamente en torno de las jícaras 
de chocolate, está revelando la influencia benéfica y vital de América. Al contrario del vino y del alcohol pendencieros de ciertos países, y del impasible té inglés, la olorosa bebida de color castaño produjo la cordialidad expansiva, el ejercicio intelectual y la gracia, florida de ocurrencias y refranes.

Otro de los benefactores americanos de la humanidad antigua fue el árbol de la coca, cuyas hojas maceradas en infusiones o vinos farmacéuticos suprimían milagrosamente el dolor. La anestesia hizo posible el perfeccionamiento de la medicina y la cirugía, salvando así innumerables vidas de las asechanzas de la muerte. Las hojas amargas de la coca constituyen el símbolo de las escondidas posibilidades del nuevo Continente, en el sentido del bien universal.

La innegable contribución de América a la felicidad humana, en los pasados tiempos, fue, de este modo, múltiple: el oro que elevó el nivel de vida de los españoles, los nuevos productos agrícolas que aportaron el deleite y la salud, el espacio territorial abierto como una promesa ilimitada para todos los hombres.

EL SEGUNDO DESCUBRIMIENTO

Mas, así como despertó una gran esperanza el descubrimiento geográfico de América, en los años postrimeros de siglo XV y durante todo el siglo XVI, igualmente el descubrimiento espiritual de América en el siglo XX es un hecho trascendental que ha venido a levantar las fuerzas de la humanidad fatigada. Ese descubrimiento espiritual de América lo han realizado los mismos americanos, muchas veces empujados, es verdad, por la curiosidad o la enseñanza de Europa.

Durante el siglo XIX, los países americanos consiguieron su independencia política de la Metrópoli, mas continuó el coloniaje espiritual. La poesía hispanoamericana seguía al pie de la letra los modelos españoles. Olmedo caminaba sobre las huellas de Quintana; José Mármol, Manuel Acuña y otros imitaban á los románticos peninsulares; Joaquín González Camargo se lamentaba en el tono exacto de Bécquer ; Felipe Pardo tenía como maestro a Moratín ; Luis Benjamín Cisneros ganaba fácil notoriedad hispánica con su “Elegía a la Muerte de Alfonso XII”. Aun en las estrofas de Martín Fierro vagaban ecos de la poesía popular de la Península. Sólo en las postrimerías del siglo XIX, algunos poetas de Colombia y de otros pocos países más, acercaron sus labios sedientos a las fuentes del romanticismo alemán y el romanticismo italiano. ${ }^{1}$ Mas, el verdadero movimiento de independencia espiritual hispanoamericana se inició con el Modernismo, que no fue un conato aislado sino un fenómeno continental. Es verdad que hubo arrepentimientos y supervivencias — que los hay hasta en nuestros días-; pero el hecho es que la corriente modernista se impuso y llevó su influjo, a su vez, hasta la Península (Valle Inclán, Salvador Rueda, Pérez de Ayala, los Machado, el primer Juan Ramón Jiménez, Villaespesa y los poetas menores como Fernández Ardavín, Marquina y compañía).

Los hombres europeos empezaban a descubrir el espíritu de América. En los comienzos del siglo XX, por primera vez, las tropas expedicionarias americanas

\footnotetext{
${ }^{1}$ José Eusebio Caro recuerda a algunos a Carduccí; Julio Arboleda a los poetas germanos. Rafael Pombo es ya un precursor de la total liberación poética.
} 
desembarcaron en Europa, en defensa del derecho y la libertad de los pueblos. Jóvenes de los Estados Unidos, de México, de Venezuela, del Ecuador, de la Argentina, fueron a ofrecer su vida voluntariamente en las trincheras de Francia. Europa y el mundo comienzan entonces a hablar con esperanza de "los americanos", a los que se considera capaces de realizar las cosas más sorprendentes.

Es un hecho innegable que mientras el sentimiento de solidaridad humana y la sensibilidad democrática se manifiestan sólo en las figuras intelectuales más destacadas de Europa, o sea en la flor de la "inteligencia occidental”, los habitantes de América, sin distinción de clases, poseen estos sentimientos de modo profundo y espontáneo.

Lo que en el resto del mundo es excepcional, ya es común y general en América. Europa está haciendo actualmente, a su propio costo, un nuevo descubrimiento de América. Descubrimiento del espíritu de América que está resuelto, como en los tiempos iniciales, a contribuir a la felicidad humana, limpiando vigorosamente de todos los obstáculos el camino del futuro. Como en otras épocas, los puertos empobrecidos de Europa esperan las naves que llegan de América; pero éstas ya no se hallan cargadas de oro sino de vidas humanas, innumerables, que se ofrecen por la libertad y la creación de un mundo mejor.

\section{Amanecer del siglo XX en AmÉrica}

En el proceso de nuestra independencia espiritual de España, la aparición de Rubén Darío es uno de los acontecimientos más trascendentales. El es el gran Adelantado, el héroe de la emancipación de la poesía hispanoamericana. Lo que algunos críticos han calificado de afrancesamiento en Darío no es sino una voluntad radical de separarse del forzado itinerario español, abriendo un camino nuevo, inaugurando una aventura sorprendente de la que regresa con un inmenso botín de color y de música, con un tesoro de frescura destinado a enriquecer y refrescar la ascética aridez castellana. Darío inundó de azul y de esperanza el panorama poético, en los comienzos de nuestro siglo.

No hay que caer en el error general de suponer que Prosas profanas es la obra representativa del iniciador del Modernismo. ${ }^{2}$ Ese libro apenas es la señal, el golpe de batuta con que impuso silencio para ejecutar su propia música. Los cisnes traídos de las islas de Mallarmé, las marquesas pastoras y los sátiros verlainianos, los campesinos con nombres helénicos que pululan en esa especie de campo nudista de Samain, toda esa fauna desencadenada por Rubén Darío, no tuvo otro objeto que acabar con las últimas supervivencias del coloniaje español.

La poesía suprema de Darío, el libertador, es la otoñal y meditabunda, la de la "barba en la mano” y la acidez filosófica:

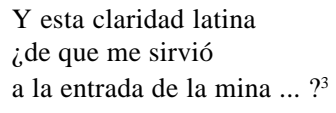

\footnotetext{
${ }^{2}$ Aún hay quienes consideran Azul como el breviario inicial de la escuela modernista.

${ }^{3}$ Del poema intitulado "Eheu".
} 
Aun a través del oscuro laberinto donde le salen al paso los enigmas eternos, resuena su poderosa orquestación verbal, su maestría musical claramente originaria de América.

En los primeros años de este siglo, el hombre americano se siente esencialmente moderno, sin tradición fija — habiendo cortado de modo voluntario las amarras hispánicascon su obsesión de aportar algo diferente al mundo. Los Cantos de vida y esperanza interpretan ese amanecer del siglo, los tres primeros lustros del Modernismo. Allí se vió que Darío no usaba el exotismo sino como elemento ornamental, como un espolvoreo de “especias americanas” para realzar el sabor de sus creaciones. Empero, permanecía inmutable, en el fondo, el alimento de filosofía, de experiencia humana y de sentimiento eterno de su poesía.

“Muy moderno, audaz, cosmopolita” se llamó a sí mismo Darío. En esos calificativos se encuentra la clave de su actitud, animada por las tres esenciales virtudes americanas. La solidaridad con el tiempo nuevo y con todos los países del mundo es el mensaje mayor que el gran poeta difundió como característica fundamental de nuestro Continente.

El coro de poetas imitadores de Rubén Darío, no añadió nada, o muy poco, al Modernismo. Hubo cantores de las pampas, los bosques, las cataratas del Nuevo Mundo. Mas, todo se esfumó en medio de una desordenada trompetería verbal, cuyos ejecutores más virtuosos fueron Díaz Mirón, Santos Chocano, Jaimes Freyre, Guillermo Valencia. ${ }^{4}$ La nota de exotismo fué extremada por Herrera y Reissig, quien supera en sus Eglogánimas a los Sonetos rurales de Samain, y obtiene en su trabajo de artífice un inusitado relieve de síntesis y universalidad.

Luego, en natural continuidad secreta al Rubén Darío de Cantos de vida y esperanza —y no en oposición, como creen algunos— le sucedió González Martínez, cuya obra democratizó la poesía, despojándola de su elemento decorativo y superfluo y haciéndola ganar en sobriedad.

Esta época —en la que hay que nombrar igualmente a Lugones y José Juan Tablada— se cerró con Huidobro y su Creacionismo que vigorizó la construcción poética, dotándola de materiales superpuestos, antes nunca usados, y de sutiles inventos, livianos y durables a la vez. La expresión idiomática se convirtió entonces en una nave libre con la proa siempre puesta hacia un horizonte desconocido. (Ultraísmo llamaron a esta escuela poética en España, reconociendo su procedencia de ultramar, al mismo tiempo que sus rumbos extremos.)

\section{La BUENA SOMBRa DE Walt WhitMan}

Ya desde fines del siglo pasado, se iba extendiendo desde el norte del Continente una sombra patriarcal, cuya voz tenía la resonancia de los himnos y de las profecías. Esa voz de sombra llegaba envuelta en niebla con lamentos de ferryboats, en chillidos de pájaros sobre las sementeras de un país de abundancia, en cantos de gratitud de artesanos y labradores. Era la voz del dulce y bondadoso anciano Walt Whitman, habitante de grandes ciudades y campos inmensos. Hablaba del “genio de lo moderno”. Dedicaba sus oraciones al esfuerzo y al trabajo. Sus héroes eran los exploradores, los inventores, los constructores.

\footnotetext{
${ }^{4}$ Hay que añadír: Urbína, Amado Nervo, Lugones, Santiago Argüello.
} 
Nacía con él la poesía de las factorías, de la “agricultura multiforme”, de las máquinas, de la vida mercantil, de las minas, de la gestación de los nuevos Estados.

Escribía Walt Whitman cosas significativas y augurales como la "Canción del Camino Abierto", la "Canción de los Universales". ${ }^{5}$ Tenía "espíritu de amor y lengua de fuego" y aconsejaba: "las palabras sustanciales están en la tierra y en el mar, en el aire y en ti mismo". ${ }^{6}$ Iniciaba con su poesía tonificante el descubrimiento de la belleza que se esconde en la vida diaria, en los oficios humildes, en la salud, en la libertad, en la camaradería con todos los hombres de todas las razas. "The earth, that is sufficient". ${ }^{7}$ En este verso suyo se encierra toda la clave de la poesía americana, de norte y sur. La tierra es suficiente, en efecto, para la creación poética de nuestros días.

Hasta hoy sigue creciendo sin término la sombra del vigoroso viejo juvenil. Los mozos de varias generaciones le acompañan en sus himnos que constituyen la épica de la democracia. Buena sombra germinal fué para Sabat Ercasty, Gabriela Mistral, Parra del Riego, Neruda y otros más, ahora creadores de un mundo propio. De modo especial, el autor de los “Himnos del cielo y los ferrocarriles” dejó ver en su obra la enseñanza de fuerza y nobleza del patriarca norteamericano "de ágiles ojos celestes y cara de aurora entre los humos de su barba de santo natural”. ${ }^{8}$

En el fragor apocalíptico y confuso de estos años, se alcanza a oír la estremecedora voz profética

Not wan from Asia's fetiches,

Nor red from Europe's old dynastic slaughter-house,

Area of murder-plots of thrones, with scent left yet of wars and scaffolds everywhere

But come from Nature's long and harmless throes, peacefully bailed thence, These virgin lands of the Western shore,

To the new culminating man, to you, the empire now,

You promis'd long, we pledge, we dedicate ...

Thunder on! Stride on, Democracy! Strike with vengeful stroke!

And do you rise higher than ever yet $\mathrm{O}$ days $\mathrm{O}$ cities!

CIENCIA DE ARRIBA Y RAíZ TERRESTRE

Una mirada sobre el panorama poético del mundo de habla española, puede descubrir fácilmente la significación de la actual poesía americana. España, reducida a ser una esquina de Europa, en el siglo XIX, hacía esfuerzos inauditos por preservar su herencia de tradición y misticismo, a todo viento y marea. Mas, la tempestad huracanada del Romanticismo europeo iba llevándose todo entre sus torbellinos de lágrimas. De Inglaterra venía el asalto mayor, con Byron, el fundador de un doliente imperio que no tenía límites.

\footnotetext{
${ }^{5}$ En la colección Leaves of Grass. Edición con prólogo de Christopher Morley. Doubleday, Doran and Co. New York. 1940.

${ }^{6}$ Walt Whitman: "Song of Myself".

${ }^{7}$ Walt Whitman: "Song of the Open Road".

${ }^{8}$ Juan Parra del Riego: “Walt Whitman”. Publicado en Montevideo.
} 
La poesía española era una “ciencia de arriba” como gustaban llamarla sus marqueses, duques y clérigos poetas. Señalaban con esta denominación su origen celeste y su parentesco directo con la Teología y demás conocimientos religiosos. Exigía esta ciencia una serie de reglas, ligadas con las prácticas monásticas y el espíritu de la lengua latina. El hombre común no podía ser visitado por la gracia poética. San Juan de la Cruz; Fray Luis, el agustino; Lope de Vega, Familiar del Santo Oficio; Góngora, Beneficiado de la Catedral de Córdoba; Argensola, el Capellán; ésos eran los nombres mayores de la poesía o de la revelación altísima.

El Romanticismo y las reformas políticas alcanzadas por el pensamiento liberal, cambiaron un poco esa situación. Empezaron algunos hombres de la clase media española a escribir poesía; pero, para hacerlo, seguían invocando a un ser sobrenatural al que llamaban Musa y que solía bajar del cielo. Nada tenía ésta de Erato, Polimnia o Calíope, ya que su aspecto no era jupiterino sino cristiano y habitaba al lado de los ángeles.

En el siglo XX, el hombre telúrico de América hace que la poesía, por primera vez, hunda su raíz en la tierra. Lo humano, lo inmediato, ejercen por fin su poder, cuyo significado empieza a descifrarse gradualmente. La poesía se vuelve un mensaje vital que puede salir de los labios del hombre del pueblo, del indio o del negro, de cualquier ser de la especie humana. Se llega a entrever un vasto mundo no descubierto; el reino de las cosas, el imperio de lo físico. Y la poesía no vacila en penetrar en él hasta resolver su misterio.

Ese es el aporte del americano nuevo: haber encontrado la raíz terrestre del hombre. Haber iniciado una especie de "realismo poético", frente a las vaguedades metafísicas y las brumas románticas. Ese realismo poético americano ha alcanzado a remozar aun la poesía española, en sus mejores exponentes de esta hora, desde Unamuno y Antonio Machado hasta Rafael Alberti, Vicente Aleixandre y Luis Cernuda.

A los “cánticos y sonetos espirituales" han sucedido cantos y sonetos materiales, “elogios de la materia” y poemas humanos. Gabriela Mistral canta a la "sal blanca y ciega”, a la "Santa de la sal”. Pellicer escribe sus Poemas elementales. Cardoza y Aragón, enfermo de soledad, penetra en el mundo de las "mudas materias opacas, sin forma ni sollozo”. Residencia en la tierra llama a su gran libro Pablo Neruda. Huidobro escribe una serie de poemas con el título de Ver y palpar. Alberto Hidalgo publica Dimensión del hombre; Francisco Luis Bernárdez, Cielo de tierra; Juvencio Valle, Tratado del bosque; Octavio Paz, Raíz del hombre. Esta obsesión humana y terrestre - fruto de un conjunto de países en parte inexplorados, donde conviven más o menos pacíficamente hombres de las más variadas razas-, es la contribución de América a la poesía universal.

\section{Clave de lo nativo}

La revalidación poética de la realidad circundante produjo, de modo natural, el "Nativismo", con un sentido de afirmación y defensa, en los países de gran inmigración extranjera como la Argentina, Chile, Uruguay. En la zona afroamericana, más o menos en el mismo tiempo, nació la “Poesía Negra”, y, en el resto de América, el “Indigenismo”. La exaltación de la vida inmediata, del paisaje nativo, de la morada terrestre, condujo de esta manera al hombre americano al descubrimiento de su mundo propio e intransferible. 
Hay algo como la vertiente original y remota de esta clase de poesía, en la "Memoria sobre el cultivo del Maíz en Antioquía”, oda vernácula, de gran color y movimiento. ${ }^{9}$ Igualmente el Nativismo tuvo un precursor no declarado en Leopoldo Lugones, el de Odas seculares. También se puede calificar como nativistas a Carriego, Ramón López Velarde, Pedro Leandro Ipuche, Luis C. López, Alberto Guillén, José Eustasio Rivera, Jorge Luis Borges, a pesar de que su creación poética no se ha realizado únicamente en ese sentido. Muchos de entre ellos, tienen, sin embargo, más luz autóctona tal vez que el propio Fernán Silva Valdés, el supernativista, quien se propone extraer el perfume poético de las labores agrícolas, de la incorporación de los inmigrantes rubios y de la vida popular, en "romances chúcaros”, aborígenes o salvajes. Mas, el romance no es una forma de expresión americana y no le quedan muy bien los abalorios sobre su fina y clara piel que está delatando su linaje español. El Nativismo culto y matizado, interpretativo y ennoblecedor, de Jorge Luis Borges, o el irónico, profundo y musical de López Velarde — uno de los grandes poetas de nuestro tiempo- son altísimas y provechosas lecciones poéticas.

En los países donde existen aún considerables masas indígenas —Ecuador, Perú, Bolivia- apareció el Indigenismo como una vuelta hacia la sencillez y una protesta por las condiciones actuales de los primitivos dueños de la tierra. Ya no era la pintura del "buen salvaje”, sino el grito reivindicador por el hombre oprimido. El vocerío indigenista no ha dejado huellas mayores; pero fue, en su tiempo, un puntual despertador de la conciencia y una segura semilla de las actuales novelas de indios.

No hay que confundir el Indigenismo con el indianismo o el costumbrismo. La literatura indianista ha existido siempre, desde los días de la colonización española en América. ${ }^{10}$ El costumbrismo, por su parte, se ha aprovechado solamente del elemento decorativo y no ofrece ningún contenido social. Tampoco se puede reducir el Indigenismo a un fenómeno local, como lo hace Alberto Tauro, quien lo califica erróneamente de “nacionalismo literario” o de “trasunto de la peruanidad”. El Indigenismo es mucho más vasto que todo eso: es la expresión de un sector humano, más allá de las fronteras nacionales, significando un anhelo de integración americana, por medio de la incorporación de una raza, originaria y olvidada, a la aventura común.

Tanto el Indigenismo como el Nativismo son formas de interpretación de la realidad o, más bien, de contacto directo con la tierra. Naturalmente, el vocabulario en que se han estructurado no siempre está hecho de materiales transparentes y necesita de una clave auxiliar; pero sus valores expresivos — o subversivos — son de una intensa y palpitante eficacia. ${ }^{11}$

\footnotetext{
${ }^{9}$ Este poema hizo famoso al colombiano Gutiérrez González.

${ }^{10}$ Indiano se llamaba en España al español que volvía de "las Indias”. Luego se aplicó por extensión a todo lo americano. Novelas indianistas fueron, por ejemplo, la de Matto de Turner o Juan León Mera (Cumandá). Y los poemas del género, desde el de Ercílla hasta el de Zorrilla de San Martín (Tabaré).

${ }^{11}$ Entre los poetas indigenistas peruanos, hay que nombrar especialmente a Alejandro Peralta, Luis Fabio Xammar, José Varallanos, Guillermo Mercado.
} 
POEsía NEGRA PARA DANZAR

Ese mismo imperativo de integración americana da origen a la poesía negra en Puerto Rico, Cuba, Santo Domingo, Haití y en todas las costas del Caribe. Aun en el Río de la Plata se oye una "guitarra negra" tocada por un hombre blanco que tiene la nobleza de lamentar la suerte de sus hermanos de color oscuro. Nada tiene que ver, sin embargo, esta poesía con el "Arte negro" que tuvo años de abundancia en Europa después de la primera guerra mundial. Esa modalidad invadió principalmente la pintura y el relato, y no pasó de ser otro de los refinamientos europeos. Las "historias de negros"12 estuvieron de moda y el negrismo pictórico y plástico fue considerado como la flor de lo moderno. No era sino una nueva fuente de exotismo para la Europa cansada. Únicamente se lo usó como condimento fuerte y no llegó a ser poesía.

En los países hispanoamericanos, el negrismo obedeció a un imperativo interior y produjo un movimiento poético definido: Poesía negra para danzar, en contraposición de la poesía negra para cantar, que se produce en los Estados Unidos. Tomando en cuenta solamente la geografía y el tiempo, se podría llegar a la conclusión de que una corriente de influencia poética se produjo desde la Louisiana y Florida hacia Cuba, Puerto Rico y las Antillas en general. Los ecos de nostalgia de la música negra, de los cantos de los cargadores de algodón y de los negro spirituals, parecen haber viajado en el viento del Mar Caribe hacia las playas hospitalarias. Hay la idea común, igualmente, de que ciertos poemas de Vachel Lindsay son las semillas de la flora poética antillana. Pero “The Congo” —al que el autor le da el subtítulo de "estudio de la raza negra”-, "General William Booth enters into Heaven”, “Simon Legree”, “John Brown” y los demás poemas de color escritos por Lindsay, presentan una preocupación religiosa, moral e ideológica y están hechos para ser recitados o cantados individualmente o en coro. La fuente de donde mana toda esta poesía es la canción negra. Lindsay quiere que se canten sus poemas y él mismo señala el tono y los instrumentos con que ellos deben acompañarse. En "General William Booth enters into Heaven”, el poeta pone esta nota: "Para cantar en el tono de 'Blood of the Lamb' con los instrumentos indicados”. Estos instrumentos son el tambor, el banjo y la flauta. ${ }^{13}$

Lo que diferencia a la poesía negra hispanoamericana es que su inspiración arranca de la danza. No son ya las canciones de trabajo y los himnos. Nicolás Guillén y José Zacarías Tallet escriben “rumbas”, Pereda Valdés evoca “el candombe”, Luis Palés Matos llama a uno de sus poemas "Danza negra”. Ya no existe la medida de oro del poema sino el ritmo de la maraca, el sonido preciso del timbal. Los poemas de Ballagas, Tallet, Palés Matos, se pueden bailar. La conga del Brasil y de Cuba, la plena de Puerto Rico, el alfandoque del Ecuador, la rumba antillana, el tamborito de Panamá, son aprisionados en vocablos onomatopéyicos, en giros imitativos, y traen un temblor de sensualidad y de oscuros anhelos.

\footnotetext{
${ }^{12}$ Título de un libro de relatos de Paul Morand.

${ }^{13}$ Igual cosa podría decirse de Langston Hughes, quien reconoce como su maestro a Líndsay y aspira a ser el cantor popular de los negros norteamericanos.
} 
Mas, el aporte de la poesía negra no sólo es de música, sangre, “animalidad y belleza”, sino, sobre todo, de reparación social, de incorporación de un rasgo que faltaba para completar el perfil total de América. Nicolás Guillén ha expresado certeramente este aspecto humano:

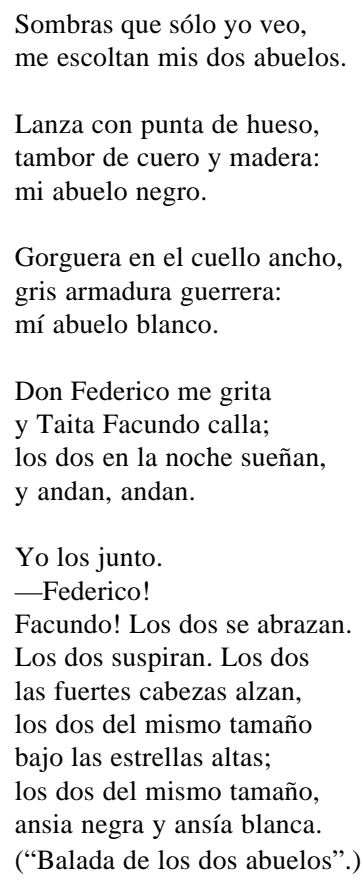

LA POESÍA SOCIAL HISPANOAMERICANA

Al mismo tiempo que la poesía negra y la poesía indigenista, apareció la poesía social, en sucesivas jornadas, desde México hasta la Argentina. Se trataba de un movimiento de insurrección espiritual contra las malas condiciones imperantes entre las clases bajas, los obreros y los campesinos. Era también una especie de afirmación de "independencia con respecto al pasado propio”, usando de una expresión de José Gaos. ${ }^{14}$

Esta poesía social invitaba a la acción, se hallaba sacudida de imprecaciones y amenazas y hacía uso de vocablos ardientes con los que pretendía inflamar el mundo. Su principal arma era el clamor. Intentaba llegar al pueblo y, para ello, trataba de ser lo más objetiva posible, lo más simple y esquemática, hasta constituir lo que se llamó “cartel proletario” o manifiesto lírico. Estos carteles, aunque despojados muchas veces del más elemental ornamento poético, quedarán, sin embargo, como el documento de una época

${ }^{14}$ José Gaos: “Teoría sobre los fundamentos de una Filosofía Hispanoamericana”. 
y servirán para comprender mejor el proceso de la emancipación espiritual de nuestro Continente.

Es indudable que los poetas hispanoamericanos se adelantaron a los otros poetas del mundo - con excepción de los rusos - en incorporarse a las masas populares y formular el mensaje de su dolor y su anhelo. En Europa no había poesía social. Había únicamente poesía del pueblo, unanimismo francés, expresionismo alemán, futurismo, cubismo, vanguardismo universalista. En España, el ejemplo de independencia dado por América empezaba a florecer cuando sobrevino la reacción de los generales y los señoritos, en 1936.

En cuanto a la influencia rusa que se ha creído encontrar en la poesía social hispanoamericana, no pasa de ser una similitud de técnica y de sentimiento. Cuando se inició la poética revolucionaria en nuestros países, nadie sabía leer el idioma ruso y no se había traducido al español o al francés sino un poco de Block, Essenine o Mayakowsky, o sea los poetas que menos se parecen a las figuras representativas de nuestra poesía social. Hay más similitud entre los poetas proletarios hispanoamericanos y los constructivistas como Elías Selvinsky, Guerassimov, Ladovieff, Svetloff ; mas, se puede asegurar que esta similitud es enteramente casual, ya que las obras de estos últimos no han llegado a América. (Muy pocos han leído seguramente la traducción francesa del "Hierro Floreciente” o "La Fábrica de Alas de Fuego" de Guerassimov). La influencia de la literatura rusa fue posible en la novela, y esto, únicamente, de modo temporal. La razón principal de tal atracción se debió a las condiciones similares de feudalismo agrario y amanecer del industrialismo, existentes en estas dos diversas partes del mundo.

La contribución de la poesía social a la expresión auténtica del espíritu americano, es apreciable en relieve y en número, a lo largo del mapa continental: en Chile, el violento y potente Pablo de Rokha, quien forcejea en una "gran temperatura” de motores y masas; Juan Marín; Gerardo Seguel; Julián Petrovick. En el Perú, el contradictorio fustigador celeste y terrenal Alberto Hidalgo, el de "Biografía de la palabra Revolución”; César Vallejo; Magda Portal; Xavier Abril, el de la significativa "Declaración en nuestros días". En el Ecuador, el insobornable Manuel Agustín Aguirre de "Llamada de los proletarios”; Jorge Reyes; Miguel Angel León; Pedro Jorge Vera. En Colombia, el móvil Luis Vidales; Castañeda Aragón; Darío Samper. En Venezuela, Antonio Arraíz, el vigoroso autor de “Aspero”; Manuel Rugeles. En Cuba, Juan Marinello; Regino Pedroso; Manuel Navarro Luna y, de modo especial, el febril pero mesurado Nicolás Guillén. En Bolivia, Oscar Cerruto. En el Uruguay, Blanca Luz Brum. En Centro América, Gilberto González y Contreras; Salomón de la Selva; Claudio Barrera. En México, List Arzubide; Humberto Rivas; José Muñoz Cota y, sobre todo, Manuel Maples Arce, quien tomó gran parte de sus imágenes de la lucha política y social: "viento, dictadura de hierro", "el crepúsculo es un motín sangriento en los suburbios”, “los poetas comentan la renuncia del día”. No hubo país hispanoamericano que se mantuviera ajeno a este despertar. Es verdad que en los últimos años muchas de estas arengas y manifiestos poéticos han sido sepultados entre las ruinas de ideas, épocas y ciudades; pero, de todas maneras, debe tomarse en consideración esta etapa, en su valor justo, para comprender mejor la actitud poética actual del hombre americano. 
NERUdA, HABitANTE DE LA TIERRA OSCURA

Todo el azul del cielo ha empezado a encanecer, se ha vuelto gris. La arena del suelo no es ya más que ceniza. Es como si el mundo hubiera perdido su amable disfraz, su luminosa apariencia, sus vestiduras de colores y se mostrara en su desnudez lamentable. Los cazadores de ángeles, los coleccionadores de rosas y de estaciones, se retiran en silencio. Y Pablo Neruda, el enlutado, alza su voz franca y angustiosa y le palpa los huesos al planeta. El no "inventa cosas" cuando canta, sino que se reduce a quitarle la máscara a la realidad y denunciar su verdadero nombre y su misión secreta. Así, el viento "arrolla su bandera de lúgubre cuero", la sangre "tiene dedos y abre túneles debajo de la tierra”, el día cae "como una temblorosa tela de vaga viuda". ${ }^{15}$

La poesía se liberta hasta un grado sumo; Neruda no aspira sino a ser el hombre común, intérprete de la angustia humana en el vasto escenario terrestre. Vive "dentro de su piel y de su traje, sinceramente oscuro". Expresa lo inexpresable. Eleva a la categoría emocional los sucesos diarios, los objetos despreciados: la melancolía en las familias, las enfermedades caseras, el aceite, las camas, las botellas, los utensilios domésticos. Ofrece una imagen fiel de este mundo preñado de dolor, miseria y explotación humana.

Pablo Neruda, nacido en una pequeña ciudad de Chile a principios de este siglo, ${ }^{16}$ escribió de 1925 a 1935 su gran libro Residencia en la tierra, que da la medida de la profundidad espiritual americana. En ese libro desolado, lleno de impresiones orgánicas, se ha consignado el lamento trascendental que estremece las entrañas convulsas del hombre. Su poesía se mantiene alejada voluntariamente de toda transparencia, dejando únicamente al descubierto su viva raíz terrestre. Poesía compacta, mineral, de una dureza que muchas veces no se deja penetrar a la primera intención; pero que, luego, deslumbra con la vena inagotable de sus imágenes casi líquidas, sus presagios y sus símbolos.

El poeta de los Tres cantos materiales ha rejuvenecido y restaurado el idioma, dando un nuevo sentido a las palabras usuales, aplicando a las cosas calificativos inesperados y sin embargo exactos. Ha creado una nueva metáfora, de tamaño y densidad filosóficos. Ha puesto al desnudo lo patético y trascendental de la vida diaria. Su desprecio de los elementos retóricos, su desdén de los mitos, su vocabulario virginal, son otros tantos ejemplos de independencia que han sido seguidos sin orden, aunque no sin riesgo, por los hombres jóvenes de América.

Neruda es dueño de un mundo viviente, atropellado, y su expresión a veces es apenas un tartamudeo sibilino, un balbuceo primario. Posee una especie de ciencia de las palabras dispares. De las palabras que se mezclan en la tierra; pero que nadie había osado aún ponerlas juntas en el poema:

Y golondrinas verdes hacen nido en tu pelo,
y además caracoles y semanas, mástiles enrollados y cerezas ...

\footnotetext{
${ }^{15}$ Pablo Neruda: Residencia en la tierra. Tomo 1. Ediciones del Árbol. Madrid, 1935.
}

${ }^{16}$ Nació en Parral en 1904. Véase la "Exposición de la poesía chilena” de Carlos Poblete. 


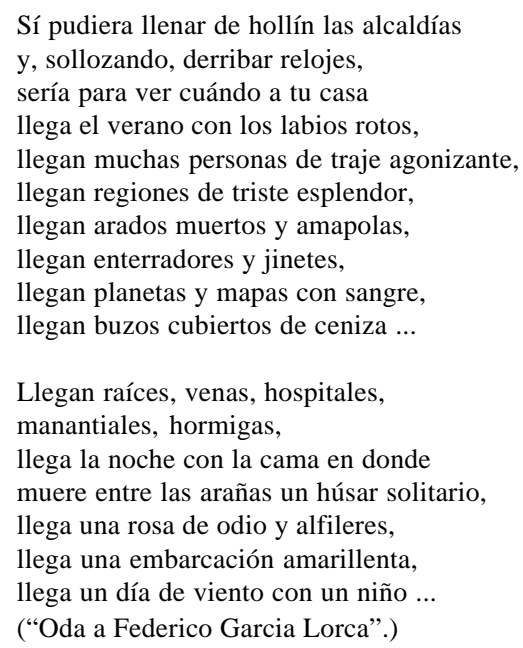

No hay nadie que haya superado a Neruda en realismo patético. Sus cantos a la materia son incomparables en castellano. Nadie ha invocado mejor las formas del mundo: “iOh párpados, oh columnas, oh escalas, —oh profundas materias agregadas y puras: ¡cuánto hasta ser campanas! — ¡cuánto hasta ser relojes! Aluminio de azules proporciones, cemento - pegado al sueño de los seres!” Este vigoroso hombre de Chile y del universo, con su piel tostada por el sol y sus ojos almendrados, ha sabido ver las cosas como no han podido hacerlo aún los surrealistas franceses. Hay mucho convencionalismo, mucha cultura ultrarrefinada, mucho elemento libresco en el Surrealismo, mientras que en la poesía de Neruda hay enigma natural, directa revelación telúrica. La tierra y el hombre son dos vasos comunicantes, por donde circula el misterio elemental:

Estoy mirando, oyendo,

con la mitad del alma en el mar y la mitad del alma en la tierra,

y con las dos mitades del alma miro el mundo. ${ }^{17}$

Mas, muchas veces, el poeta no se resigna únicamente a su papel de contemplador. Ha visto las ciudades destruidas, las muchedumbres palpitantes de heroicidad y sufrimiento y ha entrado en ellas, dispuesto a compartir el dolor colectivo. Ha escrito himnos y elegías de la guerra. Y se ha alistado, con voluntad de martirio, entre los hombres que están decididos a hacer de nuestra América la realización de la más espléndida "Patria humana”.

LA POESÍA DE LA GUERRA Y DE LA MUERTE

La sensibilidad alerta del americano nuevo se manifestó, una vez más, durante la guerra civil española, que fue la iniciación de la guerra social internacional. Numerosos

${ }^{17}$ Pablo Neruda: “Agua sexual”. 
jóvenes hispanoamericanos se trasladaron a España a dar su sangre por la causa del pueblo. Trataban de pagar de esta manera la deuda de gratitud contraída hace muchísimos años con los españoles que vinieron a América trayendo su idioma y su patrimonio espiritual.

Entre las ruinas humeantes de las ciudades bombardeadas, entre los asaltos de los tanques de fabricación alemana y de la caballería mora, nació la poesía de la guerra, escrita por hispanoamericanos. Esta poesía está representada por César Vallejo, Nicolás Guillén, Neruda, González Tuñón, Octavio Paz, Pita Rodríguez. Poesía que levantaba su signo de muerte y de esperanza, entre el polvo y la sangre, entre el amargor de la injusticia y la derrota. Los sembrados estaban cubiertos ya únicamente de espigas de fuego y humo, de cadáveres de campesinos, de ruinas de viviendas humildes. El Hombre común se sentía acosado por todas partes, por sus tradicionales enemigos. Si éstos triunfaban en España, la vida de las clases populares se hallaría amenazada en el resto del mundo. Así lo comprendieron Vallejo, Neruda, Guillén y los otros. César Vallejo se identificó tanto con la suerte del ejército del Pueblo español que cuando éste comenzó su desastrosa retirada del Ebro, el poeta no pudo resistir tan honda amargura y murió de desesperación en un hospital francés. España, aparta de mí este cáliz es el título del libro del atormentado mestizo peruano, cuya sensibilidad universal adivinó que en el suelo peninsular se jugaba el destino del hombre.

Esta poesía de la guerra es necesariamente elegíaca, desgarrada, cósmica. Tiene de la poesía social el clamor de protesta. Es desorbitada, gesticulante a veces. Igualmente es profunda, móvil, enternecedora, filosófica. Y, sobre todo, terrestre. El realismo se extrema hasta producir impresiones casi físicas. A los cantos a la materia viviente, a los himnos pacíficos a la madera y al vino, a los símbolos del cristal y de la sal, suceden los obuses y las ambulancias, el polvo, las ruinas, la materia destrozada, el sudor, el gemido animal del hombre que muere. El cañón es el "toro de la muerte que embiste y lo derrumba todo", la sangre es irónicamente "el tomate histórico", la pólvora es "una vegetación de pesadilla”. Es “la muerte a pedazos, la muerte a torrentes hacia la mar corriendo”, según la expresión gráfica de Raúl González Tuñón en sus significativos poemas:

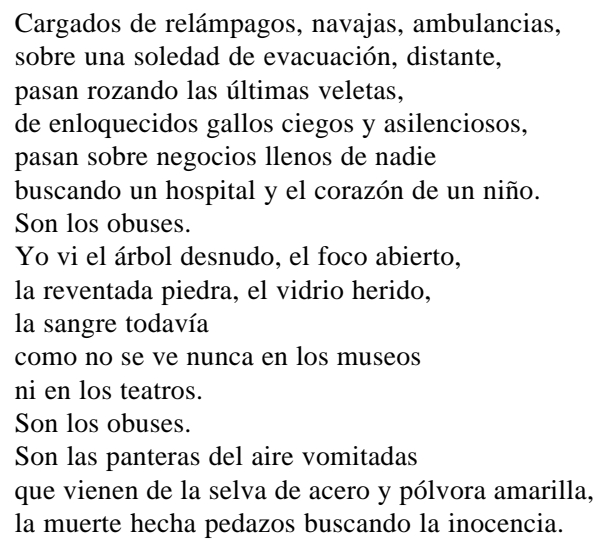


Son los obuses.

Una mitad de novia contra el balcón ardido, sus manos, ya lejanas, perdidas, estrelladas, luego la masa- sola del niño y el caballo, la muerte por la boca redonda vomitada. Son los obuses. (“Los obuses”)

El libro más representativo de esta poesía de la guerra es, sin duda, España en el corazón (Himno a las glorias del pueblo en la guerra) de Pablo Neruda. La muerte tiene allí un nuevo sentido de palingenesia, de fusión con la tierra. Después de ese libro han aparecido otros muchos de igual índole en cada uno de los países hispanoamericanos; pero sólo unos cuantos nombres permanecen hasta nuestros días. Entre los más notables se hallan: Paso de sombra de Cruchaga Santa María, La muerte en Madrid de González Tuñón, Cantos para soldados y sones para turistas de Nicolás Guillén, No pasarán de Octavio Paz. También han escrito poemas de la guerra, Huidobro, Xavier Abril, Alejandro Carrión, José Ramón Heredia, Eduardo Anguita, Antonio de Undurraga, Volodia Teitelboim. ${ }^{18}$

Con el derrumbe del frente militar en Cataluña y el éxodo del pueblo español, quedó flotando en el espíritu hispanoamericano una impresión de desaliento y de muerte, que ha ido afirmándose más aún con la destrucción de las ciudades europeas, la caída de Francia y los continuos desastres de los Estados democráticos. Esa presencia de la muerte es particularmente notable en la poesía mexicana de estos últimos años. Ya en 1936 había publicado Ortiz de Montellano su Muerte de cielo azul, libro inesperado y transparente, al que siguieron Cripta de Torres Bodet (1937), Nostalgia de la muerte de Villaurrutia. (1938), Muerte sin fin de José Gorostiza (1940). Esta última obra es la revelación de un poeta en ejemplar madurez, dueño de un vocabulario justo y de una imagen compacta y lúcida. En Gorostiza el factor telúrico se une a la cultura y a la inteligencia para producir una equilibrada síntesis. La siguiente muestra es algo de lo más original que se ha escrito sobre el agua inconstante, imagen de la vida cambiante y fugaz que es una especie de muerte continua y sin término:

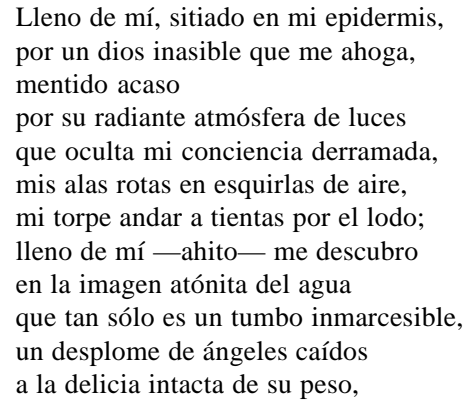

${ }^{18}$ En Buenos Aires se editó en 1938 un libro, España heroica, donde se hallan igualmente otros nombres de poetas hispanoamericanos de la guerra. 


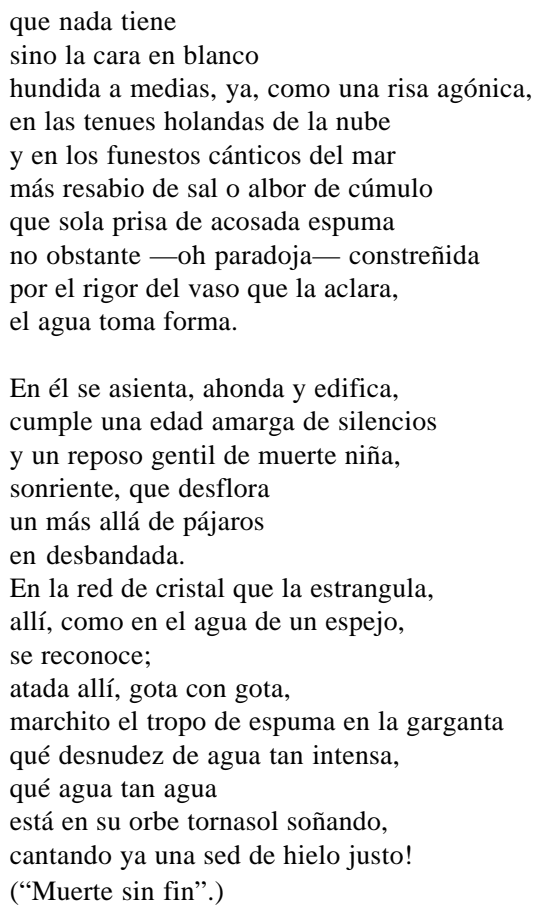

Muy diferente es, por cierto, la muerte invocada por Luis Cardoza y Aragón, la "humilde reina del eclipse" que existe en un "clima eterno de color de himno", la muerte cubierta con un "gran uniforme sin botones y solos guantes blancos ya sin tacto que no cansan". ${ }^{19}$

ACTITUD DEL HOMBRE NUEVO

Desde el Modernismo hasta la poesía actual hay, en resumen, una línea continuada, una especie de órbita completa dentro de la cual han ido apareciendo el Nativismo, el Indigenismo, la Poesía Negra, la Poesía Social, el Nerudismo, la Poesía de la Guerra . ${ }^{20}$ Todas estas diferentes manifestaciones son facetas auténticas del espíritu americano. Fuera de la órbita quedan el surrealismo trasplantado, el neo-culteranismo, la imitación de las formas españolas caducadas como en el caso de El buque de Francisco Luis Bernárdez. ${ }^{21}$

\footnotetext{
${ }^{19}$ Luis Cardoza y Aragón: El sonámbulo, Guatemala, 1937.

${ }^{20}$ Hay que añadir el "Whitmanismo" que tuvo numerosos discípulos.

${ }^{21} \mathrm{O}$ de ciertos otros poetas que se han adueñado del secreto formal y técnico de El cántico espiritual.
} 
El hombre nuevo de América reconoce como su misión primera el descubrimiento espiritual de su continente nativo. Este descubrimiento consiste en saber ver en torno, en interpretar el lenguaje verdadero de los diversos componentes raciales de la población mestizos, indios, negros, blancos_- y en captar el mensaje del hombre eterno que se resiste a sucumbir bajo el peso de la explotación, la injusticia y la guerra. El americano de nuestros días — en el norte y en el sur - tiene una mirada nueva, virginal. Obedece al mandato telúrico. Posee un agudo sentimiento de lo inmediato, lo que constituye la base de su extraordinario realismo. Su capacidad de comprensión y su experiencia sensorial le llevan fácilmente a la síntesis. Su sentimiento de fraternidad humana le conduce, de modo lógico, a su anhelo de solidaridad universal.

En la producción poética de estos últimos años se puede observar con claridad una fuerte corriente de Universalismo ; pero de un nuevo tipo que no excluye las diferencias locales. No se trata del antiguo universalismo nivelador que quería - y quiere aúnsuprimir de cualquier manera las distintas particularidades, sino de un nuevo universalismo integrador que prefiere sumar antes que destruir, conservando la variedad dentro de la unidad humana. Esta es una de las características más importantes de América, aquello que ayuda a comprender mejor el significado de su espléndido esfuerzo. América aspira a realizar el ideal de "una humanidad unida colaborando en la construcción de una torre prodigiosa”. ${ }^{22}$ Este ideal o sueño es viejo en el mundo, es verdad, pero los métodos de dominación militar con que se ha pretendido llevarlo a cabo han sido los menos apropiados. ${ }^{23}$ Sólo en un conjunto de Estados libres, unidos voluntariamente y poblados por hombres libres de todas las razas es posible la ejecución de tan magnífico sueño. América está destinada a esta obra que acrecentará la felicidad humana.

El hombre nuevo de nuestro Continente quiere contribuir con su poesía de construcción y de esperanza. Su actitud es la del aprendiz que está esperando el alba para levantar la gran arquitectura, y aprovecha las últimas horas de la noche para revisar sus materiales atesorados y probar sus utensilios. En esta hora de espera y de preparación, en esta "hora del hombre” — según expresión feliz de Huidobro— hay todavía vacilaciones y sombras. Y profusión de caminos y de rumbos; pero todos llevan a la construcción de la alegría. A la colina donde se levantará la arquitectura anhelada.

Volumen VII

Febrero 1944

Número 14

\footnotetext{
22 Paul Valéry: "Variété li”.

${ }^{23}$ Este fue el caso de la Roma de los Césares, la España de Carlos V, la Francia de Napoleón, y de todos esos Estados que han pretendido ser Amos del Mundo.
} 